\title{
Community protection of the Manas Biosphere Reserve in Assam, India, and the Endangered golden langur Trachypithecus geei
}

\author{
Robert H. Horwich, Rajen Islari, Arna b Bose, Bablu Dey \\ Mahesh Moshahary, Nirmal Kanti Dey, Raju Das and Jonathan Lyon
}

\begin{abstract}
The Golden Langur Conservation Project in Assam, India, was initiated to involve local NGOs and communities in protecting the Endangered golden langur Trachypithecus geei and its habitat on a regional basis within a complex political situation. Since langurs are leaf eaters they are dependent on forests. The Project area, once dominated by militant action and ethnic violence, is in a densely populated area and formerly suffered much illegal deforestation and accompanying reduction in the golden langur population. The Project began with two NGOs and evolved into the formation of a forum of five NGOs focusing on a large proportion of the golden langur range in Assam, and eventually included $>11$ newly formed community-based organizations. Each NGO focused on nearby Reserve Forests and their resident langur populations and adjacent human communities. The community-conservation tools used included (1) initial local community awareness campaigns, (2) formation of local Forest Committees and Self Help Groups, (3) a major regional awareness campaign about the golden langur and its forested habitat in the Manas Biosphere Reserve, and (4) creation of a number of village-based Forest Protection Forces. The Golden Langur Conservation Project has resulted in an increase in the total Indian population of golden langurs, control of illegal logging and poaching in two isolated Reserve Forests by formation of a protection force of surrounding village groups, and curtailing illegal logging and increasing forest protection in the Reserve Forests of the Manas Biosphere Reserve by the formation of 10 tribal, government-sanctioned volunteer Forest Protection Forces. The Project created an atmosphere of community awareness of the golden langur and its forests
\end{abstract}

Robert H. Horwich (Corresponding author) Community Conservation, 50542 One Quiet Lane, Gays Mills, WI, USA. E-mail ccc@mwt.net

RAJEN IsLARI Green Forest Conservation, Kokrajhar District, BTC (Assam), India

Arnab Bose, Nirmal Kanti Dey and Raju Das Natures Foster, Bongaigaon, Assam, India

Bablu Dey Green Heart Nature Club, Kokrajhar, BTC (Assam), India

Mahesh Moshahary New Horizon, Bongaigaon, BTC (Assam), India

JonAthan Lyon Department of Biology, Merrimack College, North Andover, Massachusetts, USA

Received 10 December 2007. Revision requested 14 March 2008.

Accepted 20 May 2008. and community interest within the region, with communities taking responsibility for protection of regional forests.

Keywords Assam, community-based conservation, golden langur, India, Manas Biosphere Reserve, Trachypithecus geei

\section{Introduction}

7 he Golden Langur Conservation Project was initiated 1 in Assam, India, to create regional change for conservation, focusing on protection of the golden langur Trachypithecus geei and its habitat, through community involvement. Regional change through community participation, achieved in an earlier project in Belize, Central America, which focused on the black howler monkey Alouatta pigra (Young \& Horwich, 2007), was used as a model for the Project in Assam. Although the Golden Langur Conservation Project is located in India the question is universal: how do you motivate communities on a regional scale to protect their natural environment?

The Project's focal species, the golden langur, is endemic to western Assam and southern Bhutan, and is categorized as Endangered on the IUCN Red List (2008). It inhabits lowland evergreen, semi-evergreen and moist deciduous forests within the Brahmaputra River valley of India and the foothills of the Black Mountains of Bhutan (Srivastava et al., 2001; Bezbaruah, 2004; Biswas, 2005). In healthy forests the species is arboreal (Wangchuk, 1995), depending on the forest for its diet of leaves, seeds, fruits and flowers (Biswas, 2002; Srivastava, 2004). In severely disturbed forest fragments troops exploit village fruit crops and ground crops. With a global population of 4,500-5,000 (Biswas, 2005), and with c. 1,500 in Assam (Srivastava et al., 2001) and the remainder in Bhutan (Wangchuk, 1995), the golden langur is probably India's most threatened primate (Mukherjee \& Southwick, 1997). Long-term survival depends on genetic exchange but much of the golden langur population is fragmented (Biswas, 2005).

The Golden Langur Conservation Project began as a conservation initiative to extend the work of the IndoUS Primate Project of 1994-2001, which studied the nine species of primates in the seven north-eastern states of India. To test methods of community conservation 
developed in Belize (Young \& Horwich, 2007) and the USA (Horwich, 2005), we selected Assam because of the challenging situation (a high human population, severe deforestation and complex politics).

Recent political upheaval in western Assam began with the unrest of Bodo tribal groups, in the early 1980s, who wished to establish an autonomous Bodoland state. In 1998 two militant groups, the Bodo Liberation Tigers and the National Democratic Front of Boroland maintained ephemeral bases in the Assam forests, threatening government staff and politicians and preventing the Assam Forest Department from protecting the Reserve Forests and protected areas of western Assam. The situation was compounded by ethnic violence in 1996-1998 between the indigenous Bodo people and the Santhals, tribal people who were translocated from peninsular India to Assam by the British colonial government for labour in the tea plantations in c. 1850 . This conflict resulted in 250,000 refugees in camps, mainly along the highway south of the Kachugaon, Ripu and Chirrang Reserve Forests (Fig. 1).
This situation led to major deforestation, with local people cutting illegally for smugglers and gaining a pittance from the cut logs. With no government protection, compounded by corruption and fuelwood sales, 50\% of western Assam's forests were destroyed.

The Golden Langur Conservation Project was initiated in 1998 in the midst of this situation, working initially with a community-based organization and a non-governmental organization (NGO), Green Forest Conservation and Nature's Foster, respectively. Nature's Foster had discovered golden langurs in Kakoijana Reserve Forest in 1996 (Bose, 1997) and had begun focusing on their protection. As the project achieved higher visibility it attracted other regional NGOs, independent researchers and conservationists, and new community-based organizations, to form the Manas Biosphere Conservation Forum, focused on the golden langur and the Manas Biosphere Reserve forests (Fig. 1).

Here we describe the methods and tools used to motivate both professional conservationists and inhabitants across the entire Indian range of the golden langur in

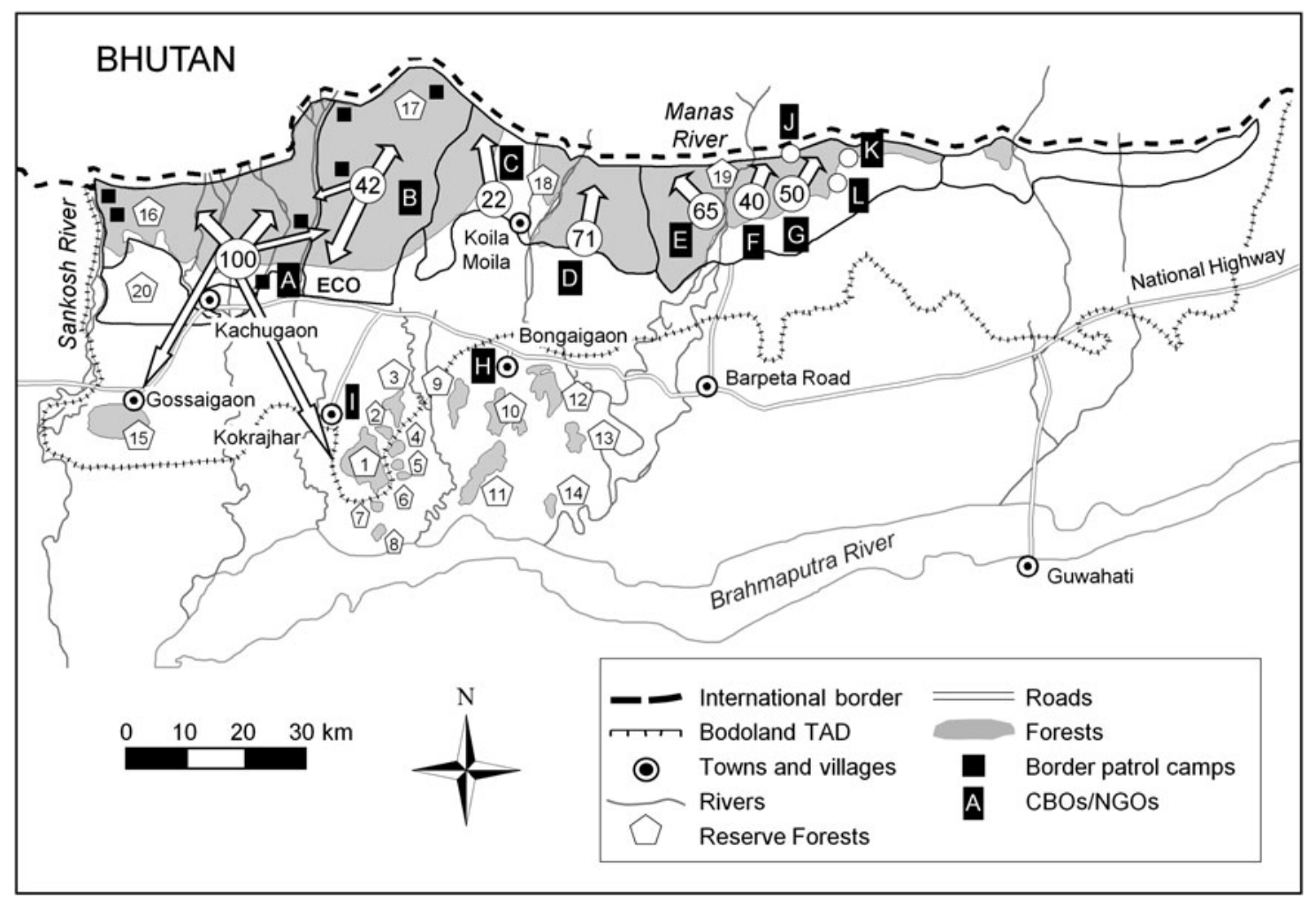

FIG. 1 The range of the golden langur Trachypithecus geei in western Assam. The Manas Biosphere Reserve (outlined in black) extends along the Bhutan Border within the Bodoland Territorial Administrative District (TAD). Ten community-based organizations (CBOs), represented by letters, have Forest Protection Forces (represented by circles with the force number inside) that patrol the areas where the arrows point: A, Green Forest Conservation; B, Biodiversity Conservation Society; C, New Horizon; D, Raigajli Ecotourism and Social Welfare Society; E, Panbari Manas National Park Protection and Ecotourism Society; F, Swarnkwr Mithinga Onsai Afut (Basbari range); G, Manas Maozigendri Ecotourism Society; J, Manas Bhuyapara Conservation and Ecotourism Society; K, Manas Souchi Khongkar Ecotourism Society; L, Manas Agrang Society. The two NGOs are Nature's Foster (H) and Green Heart Nature Club (I) based in Bongaigaon and Kokrajhar, respectively. The Reserve Forests (RF) and other areas are represented by numbers in pentagons: 1, Chakrashila Wildlife Sanctuary; 2, Nayekgaon; 3, Nadangiri RF; 4, rubber plantation; 5 Bheskamari RF; 6, Bangaldoba RF; 7, Singram RF; 8, Sampamon RF; 9, Bhumeshwar RF; 10, Nakkati RF; 11, Bhairab RF; 12, Kakoijana RF; 13, Bamungaon RF; 14, Kharagaon RF; 15, Guma RF; 16, Ripu RF; 17, Chirrang RF; 18, Manas RF; 19, Manas National Park; 20, Kachugaon RF. ECO indicates an area that is being reforested (see text for details). 
western Assam. We report the results of the community conservation intervention that led to almost complete community protection of golden langur habitat, including the Manas Biosphere Reserve, and an increase in the Indian population of golden langurs (Ghosh, 2008a,b; Anon., 2009; J. Biswas, unpubl. data).

\section{Study area}

The main golden langur range in Assam lies within the Manas Biosphere Reserve along the border with Bhutan, from the Sankosh River in the west to the Manas River in the east, in the Kachugaon, Ripu, Chirrang and Manas Reserve Forests. The Biosphere Reserve is an important forest corridor for elephants Elephas maximus and tigers Panthera tigris. Reserve Forest is a forest category that has little formal protection. The only formally protected area for golden langurs within the Manas Biosphere Reserve is a small portion of the Manas National Park west of the Manas River. Some smaller Reserve Forests that extend south almost to the Brahmaputra River, isolated from the Manas Biosphere Reserve forests and from each other, also contain golden langur populations (Choudhury, 2002; Deuti, 2005; Fig. 1). The main efforts of the Golden Langur Conservation Project in these areas focused on Kakoijana and Nadangiri Reserve Forests and Chakrashila Wildlife Sanctuary (Fig. 1). Chakrashila Wildlife Sanctuary, dedicated to the golden langur (Dutta, 1996; Datta, 1998), is the largest Indian forest outside the Manas Biosphere Reserve that contains the species.

There are proposals to extend the Manas National Park to include the eastern part of Manas Reserve Forest and to make the remaining forested areas of Kachugaon, Ripu, Chirrang and the western Manas Reserve Forests a Wildlife Sanctuary, which would give them stronger formal protection. The illegally deforested southern Reserve Forests have been proposed as Community Forests for community restoration programmes. Five NGOs form the Manas Biosphere Conservation Forum: Aaranyak of Guwahati, Nature's Foster of Bongaigaon, New Horizon of Koila Moila, Green Heart Nature Club of Kokrajhar, and Green Forest Conservation of Kachugaon. The USA-based Community Conservation initiated the Golden Langur Conservation Project in 1998 to protect and enhance the golden langur populations in this region and serves in an advisory capacity for the Forum.

\section{Methods}

\section{Community awareness campaigns}

The project began with a series of community meetings in the western Reserve Forests where Green Forest Conservation focused its efforts. Since Nature's Foster had discovered a small population of golden langurs in Kakoijana Reserve Forest in 1996 (Bose, 1997) this NGO began similar meetings with the communities around Kakoijana (Fig. 1).

Because of potential danger from militant groups trips into the forest that were arranged by government officials, when they included RHH, were accompanied by army and police. Later, trips were arranged by NGO workers, who sent word through the community network to inform the militants of our presence and to gather villagers for the meetings. During 1998-2000 Green Forest Conservation addressed villagers in c. 80 villages in the Kachugaon, Ripu and Chirrang Reserve Forests, and Nature's Foster addressed another 20 villages surrounding Kakoijana Reserve Forest. After formal meeting rituals we addressed the villagers to explain the purpose of our visit. We spoke of the importance of the forests and wildlife to local people, explained that the langurs occur only in that area, and emphasized that we needed the help of the villages to protect the forests. These community awareness sessions were attended by groups of up to 300 villagers. Similar sessions continued in later years at lesser frequencies, and were used in other areas as other NGOs joined the project.

\section{Community development}

At the project's beginning, NGO members attempted to stop illegal woodcutting whenever they encountered it. This strategy had little success and so, in 1999, they began community awareness programmes that, by 2003, had evolved into community reforestation programmes with the formation of Forest Committees and Self Help Groups for economic development.

Forest Committees Both Green Forest Conservation in Ripu and Kachugaon Reserve Forests and Nature's Foster in Kakoijana Reserve Forest began working with villages in 1999-2000 to create Forest Committees to enlist their help in conservation activities, supporting the creation of plant nurseries and the protection of regenerating forests. We were aware at that time of Joint Forest Management programmes (Poffenberger \& Gean, 1996), developed by State Forestry Departments across India since 1990 (Rastogi, 2000). However, when Joint Forest Management was introduced in Assam in 2001 the Golden Langur Conservation Project already had Forest Committees carrying out community reforestation programmes and local NGOs were concerned that Assam law minimized community participation and benefits. Green Forest Conservation and Nature's Foster continued their reforestation programmes but also encouraged Joint Forest Management. However, there was concern that encouraging villagers in the informal programmes was not formally backed by law.

Self Help Groups Self Help Groups, micro loans and enterprises developed in Bangladesh (Yunus, 1999) were 
initiated in India in the late 1980 s by MYRADA, a south Indian NGO, as a mechanism to help villagers better themselves economically (Wilson, 2002). There are now over a million Self Help Groups throughout India (Wilson, 2002). They are a simple but effective technique built on forming small, same-sex socio-economic groups for collectively saving money for investment (NABARD, 2004). Groups of $10-20$ villagers are tutored in group formation and dynamics. Each month members deposit a fixed amount of money in a common account that is used for small short-term loans to individuals or groups, with the loan repaid with interest stipulated by the Group. The NGO tutors connect these groups to rural banks for additional loans for micro-industries such as crop farming, animal husbandry or craft industries. In the Golden Langur Conservation Project, Self Help Groups for economic improvement were established in 2003 and integrated with the Forest Committees. At that time, Green Heart Nature Club worked with villages surrounding Chakrashila Wildlife Sanctuary and Nadangiri Reserve Forest to form Self Help Groups and Forest Committees to reforest those areas and the corridor between them (Fig. 1).

Ecotourism As the political situation calmed after 2004, with an accord signed by the Bodo Liberation Tigers and the Central Government and a ceasefire declared by the National Democratic Front of Boroland, tourism became of interest to newly formed community-based conservation organizations in the villages of the Manas Biosphere Reserve, in Ultapani (Biodiversity Conservation Society) and Koila Moila and Kalamati (New Horizon).

Research In 2006 we initiated the involvement of villagers in collecting data on the golden langurs. They have been involved in censuses, home range and food species determination and documentation of tree phenologies.

Regional awareness campaign In 2003 the awareness efforts of the NGOs of the Manas Biosphere Conservation Forum were unified under the umbrella of a regional awareness campaign. Seminars were held on community conservation and the golden langur in Bongaigaon and Kokrajar, involving communities, NGOs, government staff, politicians and members of the newly formed Bodoland Territorial Council. The media were invited to these events, often resulting in news articles and television coverage. Educational materials, such as posters, brochures, booklets and a book on the primates of north-eastern India (Srivastava, 1999), were used to raise the profile of the golden langur and the Project.

Local NGOs, with Community Conservation, initiated an awareness campaign focused on the Manas Biosphere Reserve. Although the Reserve is $2,857 \mathrm{~km}^{2}$, only Manas National Park $\left(519 \mathrm{~km}^{2}\right)$ is fully protected (Singh, 1999). The remaining $2,338 \mathrm{~km}^{2}$ is composed of Kachugaon, Ripu, Chirrang and Manas Reserve Forests which are the main range of the golden langur in India and had been largely unprotected prior to the initiation of the Golden Langur Conservation Project. Before 2005 only the Director of Manas National Park recognized the Manas Biosphere Reserve as a distinct entity. Thus, in 2005, the Forum of NGOs initiated a Biosphere awareness campaign. The first event hosted c. 8,000 visitors at Ultapani within Chirrang Reserve Forest. The celebration was held to establish the linkages of the various communities within the Manas Biosphere Reserve and provided an opportunity for education and a forum to exchange and share views among stakeholders. Ultapani village then reciprocated, holding their own event, which was attended by c. 4,000 villagers. Part of their motivation was to show the NGOs and the government that they could take responsibility for coordinating such events in the future.

Two other Biosphere celebrations occurred at Jumduar along the Sankosh River on the western boundary of the Biosphere (Fig. 1) in late 2006, followed by a celebration at Kokliabari, east of Manas National Park. Following the Ultapani precedent, villagers coordinated the events, which were financially supported by the Bodoland Territorial Council. Attendance at Jumduar and Kokliabari was c. 20,000 and 35,00o people, respectively (N.K. Dey, pers. comm.).

\section{Results}

\section{Kakoijana and Nadangiri Reserve Forests}

The integration of Self Help Groups with Forest Committees had positive impacts, including the opportunity to develop trusted, working relationships between villagers and NGOs. From this relationship new opportunities and initiatives emerged. Nature's Foster at Kakoijana and Green Heart Nature Club at Nadangiri worked with village groups to protect specific forest sections and encouraged neighbouring village groups to work together. By late 2004 villagers were actively engaged in forest protection. Examples of empowered villages of different ethnicities who were actively replanting, patrolling and protecting their forests were described by Horwich \& Lyon (2007). Most illegal woodcutting has ceased in these Reserve Forests.

The villages around Kakoijana Reserve Forest formed an association of village groups. By March 200828 communities around this Reserve Forest had formed the Pateswari Sonali Bandar aru Seuj Sangrakhan Federation (Pateswari Golden Langur and Green Conservation Federation) for protection of Kakoijana Reserve Forest. Green Heart Nature Club is working to organize the communities around Nadangiri Reserve Forest to form a similar forest protection federation and to form a formal legal community conservation area. By 2008 most illegal woodcutting had ceased in Kakoijana Reserve Forest, and the golden langur population in Kakoijana has increased from c. 100 in 1998 to c. 500 in 2008 (A. Bose, unpubl. data). 


\section{Community Forest Committees, Self Help Groups and ecotourism}

Collectively, starting in 2003, communities around Kakoijana, Chakrashila, Nadangiri and Koila Moila formed $>40$ Self Help Groups. Most have continued, with increased economic growth and micro-industries. Female groups have shown the most continuity. As part of the effort to increase participatory forest management, about 30 Forest Committees have been formed and have coordinated reforestation efforts, including overseeing the planting of $>100,000$ saplings in degraded forests. There are currently four tree nurseries managed by communities, producing saplings that are planted or distributed to other communities.

In 2005 New Horizon coordinated a 6-day tourism event at Kalamati, north-east of Koila Moila, to stimulate tourism and to reacquaint tourists with the area. The event attracted 9,000 participants and was repeated in 2007 and 2008 in Koila Moila. A second community-based organization, the Biodiversity Conservation Society, founded in 2006 in Ultapani, also became interested in ecotourism and, with volunteer labour, cleared a forest road for viewing wetlands within the forest. With support from a US Fish \& Wildlife Service grant the Golden Langur Conservation Project, with help from the Biodiversity Conservation Society and New Horizon, is constructing rural education/ecotourism centres in Ultapani and Koila Moila based on a rural education centre in Belize (Horwich \& Lyon, 1995).

\section{Community Forest Protection Forces}

In 2006, despite the government settlement with the militant groups and the election of the new Bodoland Territorial Council to administer the Bodoland Territorial Administrative District under the Assam State Government, the Assam Forestry Department was still not in control of the Reserve Forests and log smuggling still occurred at significant levels. Green Forest Conservation requested, from the Minister of the Environment, Tourism, Industry and Sericulture, the creation of an experimental Bodoland Forest Protection Force. Upon approval, 100 young people from c. 80 villages across the Manas Biosphere Reserve were enlisted as volunteers, receiving a small salary. By 2008, 10 community-based organizations had formed Forest Protection Forces to patrol and protect the forests across the Biosphere (Fig. 1).

Of the 10 community-based organizations with Forest Protection Forces, six help forestry staff to protect the Manas National Park and surrounding area. Volunteers in the Basbari range of the National Park, working with the Assam Forest Department, initiated a community-based organization (Swarnkwr Mithinga Onsi Afut) first, and later influenced the formation of other community-based organizations in the Panbari (Panbari Manas National Park
Protection \& Ecotourism Society) and Bhuyapara (Manas Bhuyapara Conservation \& Ecotourism Society) ranges of the National Park. Later the community-based organizations formed Forest Protection Forces to protect the three ranges of the National Park. The Manas Maozigendri Ecotourism Society, another community-based organization, formed in Kohkliabari in 2003, has also created a Forest Protection Force to protect the forest east of the Manas Tiger Reserve with $>50$ men. A fifth and sixth community group, the Manas Souchi Khonkhar Ecotourism Society and the Manas Agrang Society, have begun patrolling a large hilly area east of the National Park.

The four community groups working with the Golden Langur Conservation Project protect the four western Reserve Forests of the Biosphere Reserve. In addition to Green Forest Conservation, which protects the westernmost Kachugaon and Ripu Reserve Forests and New Horizon, which protects the western Manas Reserve Forest, two other community groups protect the western Reserve Forests. The Biodiversity Conservation Society at Ultapani recruited 42 young men in March 2007 for a forest protection group that trains in and patrols Chirrang Reserve Forest. The Raigajli Ecotourism and Social Welfare Society, formed in 2007 in the village of Kuklung, recruited 71 members, created a camp and were trained by two retired army personnel. Fig. 1 shows the location of these community protection forces within the Manas Biosphere Reserve. All 10 community groups continue to meet to maintain coordination across the Biosphere Reserve.

The Bodoland Forest Protection Force has been patrolling the forest since April 2006 (Plate 1), supported by the Bodoland Territorial Council, with two patrolling trucks and one large logging truck. Coordinated by RI, it is stationed at Kachugaon and Raimona within the Kachugaon and Ripu Reserve Forests, respectively. Volunteers patrol day

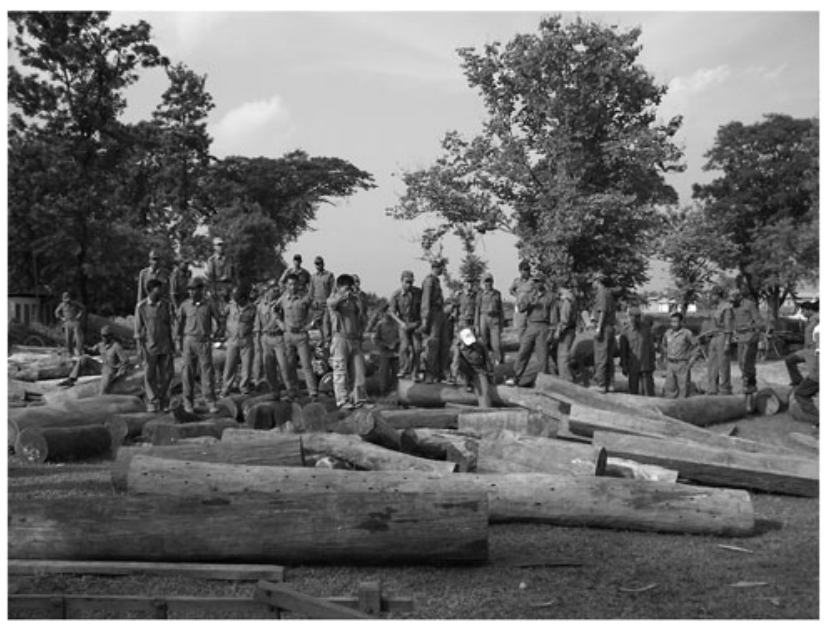

Plate 1 Bodoland Forest Protection Force members with confiscated materials at Kachugaon base camp (@) R.H. Horwich). 
and night, with forestry staff, in groups of 8-10 unarmed men and confiscate logs, tools and vehicles used in illegal activities. Prior to 1992 no logs were confiscated from these forests by the Assam Forest Department. However, from 2 April to 30 November 2006 the Bodoland Forest Protection Force confiscated the following materials from illegal activities: 823 logs, 81 buffalo carts, 110 water buffaloes, 2 vehicles, 340 bicycles, 267 axes, 89 handcarts, on bicycles, 32 hand saws, 25 ploughs, 11 rifles, eight bows, 20 arrows, one horse cart, 41 tyre tubes, and three truckloads of wood (Plate 1). The value of these materials was $>$ USD 100,000. Confiscated materials were turned over to the Assam Forest Department for sale, except the buffaloes and vehicles, which were released after a fine was paid. By 2008 the four western community forces had confiscated > USD 300,000 of illegal materials. While the Bodoland Territorial Council supports some of the Forest Protection Forces, the Golden Langur Conservation Project has raised additional salaries from the Asian Elephant Conservation Program grants of the US Fish \& Wildlife Service.

Other Indian agencies are now involved in conservation efforts in the region. The Indian Government Border Security Force has established camps in Kachugaon, Ripu and Chirrang Reserve Forests. The Security Force is an armed central government paramilitary force whose mandate is to control illegal activities in the Indian border areas. They help the Bodoland Forest Protection Force intercept illegal logging in areas around their camps. The Bodoland Territorial Council has also formed an Eco-Task Force of 1,500 retired army personnel to reforest a specific region (labelled ECO in Fig. 1).

The impact of these community forces in reducing illegal logging has been encouraging. By November 2007 the Bodoland Forest Protection Force had curtailed most illegal logging in Kachugaon and Ripu Reserve Forests. They have sent personnel to Runikata in Chirrang Reserve Forest and to Orang National Park east of the Manas Biosphere boundary. Other community groups report a $70-$ 90\% reduction in illegal logging activities. There are still, however, threats to the Chirrang Reserve Forest where $>250$ woodcutters illegally harvest fuelwood. They each carry $50 \mathrm{~kg}$ of wood out daily, on bicycles, amounting to $>30$ 0.6-1 m diameter trees per day or $>6,000$ trees per year. In Manas Reserve Forest neither the Kuklung nor the Ultapani forest protection groups have vehicles and a few major violent confrontations have resulted in serious injuries and hospitalization of their men.

\section{Community conservation momentum}

The Golden Langur Conservation Project has stimulated a high level of NGO and community conservation activity for the protection of forests and langurs. In 1998 there was a subsequent increase in golden langur research. The project began with one NGO and a community-based organization and evolved to five NGO/community-based organizations to form the Manas Biosphere Conservation Forum. The Forum may soon include the more recently formed organizations: the community-based organization of Chiponshila near Kakoijana, the Biodiversity Conservation Society of Ultapani, the Raigajli Ecotourism and Social Welfare Society of Kuklung village and the six communitybased organizations clustered around Manas National Park. This contagion of community interest, with the formation of a number of new organizations, is similar to what happened in Belize (Young \& Horwich, 2007).

The final result has been 10 community-based groups protecting the entire Manas Biosphere $(285,700 \mathrm{ha})$ that have formed a loose association under RI of Green Forest Conservation. This group has potential to develop into an association for co-management of the Biosphere Reserve with the State and Tribal governments.

\section{The golden langur}

Population surveys of the full Indian range of the golden langur now indicate a minimum of 2,200 langurs (Ghose $2008 \mathrm{a}, \mathrm{b}$ ) an increase from earlier estimates of 500 (Choudhury, 1992) and 1,500 (Srivastava et al., 2001). The estimates by Ghosh $(2008 \mathrm{a}, \mathrm{b})$ are conservative because they missed $70 \%$ of the Kakoijana population (A. Bose, unpubl. data) and the population in 2008 may have been 3,000-4,000 animals. A more recent comprehensive census of the Biosphere Reserve (Anon., 2009) recorded 4,231 golden langurs. This census, together with the southern island populations from Ghosh (2008a) indicates the Indian population to be $>5,500$ langurs. Forest canopy regeneration in Kakoijana has increased from 5\% in 1996 to $70 \%$ in 2008 to support the almost 500 langurs (A. Bose, unpubl. data).

\section{Discussion}

The Golden Langur Conservation Project was initiated to catalyse regional change in a complex political, social and ecological situation. A key strategy was to create community momentum (Westley et al., 2006) by building on a foundation of small-scale community conservation work that would reach a critical mass and result in a communitybased regional conservation movement. Faced with a situation of complexity, uncertainty and instability, and using what has been termed reflection-in-action (Schön, 1983), a group of independent NGOs working with numerous villages were able to effect regional change. The Project has shown that large-scale, regional conservation and forest protection goals can be achieved by working at the community level with a relatively small amount of funding. The project has motivated 40,000 people and begun 
community protection of a large Biosphere Reserve of $>285,000$ ha that had suffered major degradation since 1990. A key component of the methods utilized was to catalyse empowered community institutions to protect forests and wildlife. Four tools facilitated success, changing the situation from open access (Feeney et al., 1990) to an informal community co-managed system: (1) Initial community awareness campaigns in which villagers were approached as potential conservationists and their help enlisted (Horwich \& Lyon, 2007), (2) development of trust between NGOs and community groups, and interaction between Forest Committees and Self Help Groups, (3) an expanded regional awareness campaign that focused on the Manas Biosphere Reserve reached 40,000 participants, and (4) the creation of villager-based community Forest Protection Forces.

Co-management is the most effective way to involve communities (Horwich \& Lyon, 2007). Large budget, topdown Integrated Conservation and Development Projects, focusing at large scales, have not achieved high levels of success (McShane \& Wells, 2004; Horwich \& Lyon, 2007) and conservation organizations need to reconsider the small-scale community approach (Franks \& Blomley, 2004; Robinson \& Redford, 2004).

In India there is strong evidence that government and legal support encourages community participation and that communities desire to be included in the conservation process (Pathak, 2002). Community co-management can be the solution to involving communities as powerful allies in protecting forests and wildlife, something that is being sought by many governments and NGOs (Borrini-Feyerabend, 1996; Borrini-Feyerabend et al., 2004). Such co-management was instituted in Belize, in which the Community Baboon Sanctuary managed by the Women's Conservation Group was the catalyst. The Government of Belize signed agreements with community groups to co-manage 12 protected areas (Young \& Horwich, 2007) and included community comanagement in their protected area policies (Government of Belize, 2005).

The government of Madagascar, in tripling its protected areas system, has also included such policies and initiated a plan for community co-management in four regions in the south and south-west (Anon, 2008). Namibia has had success with community co-management (NACSO, 2008), establishing 50 Conservancies in the past 10 years. One major advantage for Namibian community co-management is that their programmes have had large financial incentives based on wildlife management and accompanying wildlife tourism.

The Golden Langur Conservation Project has shown that nurtured and empowered community institutions can create community co-managed protected areas. The establishment of the National Forest Policy of 1988 by Central Government was a major step in supporting community participation in regeneration and management of degraded forest lands (Wildlife Protection Society of India, 1998; Rastogi, 2000) that included Joint Forest Management and Community Reserves. However, Community Reserves (Wildlife Protection Society, 2003) can only be declared on private or community lands in India. Another alternative is state declaration of a Conservation Reserve (36A and $\mathrm{B}$ under the Wildlife Protection Act) but village representatives can only serve on an Advisory Management Committee.

However, there are two legal mechanisms that hold promise for community co-management: Village Forests and Biospheres. An older law encouraging village forest management, the Indian Forestry Act, 1927 (Krishnan, 1996; Jha, 2000; Pathak, 2002) already exists. Section 28 states that 'The State Government may assign any village community the rights of Government to or over any land, which has been constituted a reserve forest ... All forests so assigned shall be called village forests.' The government can make rules of management and payment of forest produce (Jha, 2000; Singh, 2000). This existing law, although rarely used, holds the most promise for setting up community comanagement of Kakoijana and Nadangiri Reserve Forests, and Kothari (1996) has suggested how this could be done.

The Man and Biosphere Programme (Krishnan, 1996), of which Manas is one Reserve, opens a second venue to create a community co-management institution for the Reserve Forests of Manas. However, Biospheres are not technically legal protection mechanisms and additional laws would need to be put in place to protect the community groups. The Biosphere structure for community participation, although in place, has never been used (Singh, 1999).

However, despite the lack of a legal precedent for community co-management in India, the existence of 10 strong community-based organizations in the Golden Langur Conservation Project that already have agreements to protect forests with the Bodoland Territorial Council and Assam Forest Department is a positive position from which to explore a legal community co-management system.

\section{Acknowledgements}

We thank the thousands of villagers in western Assam who are working to save their forests, the Assam Forestry Department staff, the members of the Bodoland Territorial Council, Dr Cynthia Olmstead for commenting on the article, the Margot Marsh Biodiversity Foundation for their continued support, Primate Conservation Inc. for start-up support, and the US Fish \& Wildlife Service for their recent support for the community groups. Thanks also to the Lawrence Jacobsen Award for support in developing a community-based research programme for Kakoijana Reserve Forest. 


\section{References}

Anon. (2008) Community conservation in Madagascar. CC Update, $19,1-2$.

Anon. (2009) Comprehensive census reveals 4,231 golden langurs. North East Watch. Http://ne.icrindia.org/2009/04/13/comprehensivecensus-reveals [accessed 15 August 2009].

Bezbaruah, P. (2004) Habitat Status of the Golden Langur: Presbytis geei (Khajuria) with Special Reference to Availability of Specific Food Plants. Report to Primate Conservation, Inc., Charlestown, Rhode Island, USA.

BIswAS, J. (2002) Effects of Habitat Condition (Disturbed/Fragmentation and Undisturbed) on the Activity Pattern, Feeding Ecology and Ranging Behaviour of Golden Langur (Trachypithecus geei) - A Comparative Account. Project Report. Indo-US Primate Project, Jodhpur, India.

Bisw As, J. (2005) Manas Biosphere Reserve, the last refuge of golden leaf monkey! In Heritage Manas: The Manas Biosphere Celebration Commemorative Souvenir (ed. N.K. Dey), pp. 23-25. Manas Biosphere Conservation Forum, Bongaigaon, India.

Borrini-Feyerabend, G. (1996) Collaborative Management of Protected Areas: Tailoring the Approach to the Context. IUCN, Gland, Switzerland.

Borrini-Feyerabend, G., Pimbert, M., Farvar, M.T., Kothari, A. \& Renard, Y. (2004) Sharing Power: Learning by Doing in Co-management of Natural Resources Throughout the World. IIED and IUCN/CMWG, Cenesta, Tehran, Iran.

Bose, A. (1997) Discovery of golden langur (Presbytis geei) at Kakoijana Reserve Forest, Assam. Journal of the Bombay Natural History Society, 94, 143-144.

Choudhury, A. (1992) Golden langur-distribution confusion. Oryx, 26, 172-173.

Choudhury, A. (2002) S.O.S. golden langur. The Rhino Foundation for Nature in NE India Newsletter, 4, 24.

D A T A, S. (1998) A report on the discovery of golden langur at Chakrashila Wildlife Sanctuary and its conservation. Tigerpaper, $25,23-26$.

Deuti, K. (2005) Golden langurs in fragmented habitats around Manas: will they survive? In Heritage Manas: The Manas Biosphere Celebration Commemorative Souvenir (ed. N.K. Dey), pp. 15-17. Manas Biosphere Conservation Forum, Bongaigaon, India.

DutT A, S. (1996) Battling to protect the environment: Chakrashila Wildlife Sanctuary. Participation \& Governance, 3, 3-10.

Feeny, D., Berkes, F., McCay, B.J. \& Acheson, J.M. (1990) The tragedy of the commons: twenty-two years later. Human Ecology, $18,1-19$.

Franks, P. \& Blomley, T. (2004) Fitting ICD into a project framework: a CARE perspective. In Getting Biodiversity Projects to Work (eds T.O. McShane \& M.P. Wells), pp. 77-97. Columbia University Press, New York, USA.

Gнозн, S. (2008a) Report on Population Estimation of Golden Langur (Southern Population) in Chakrashila Wildlife Sanctuary and Reserve Forests Under Kokrajhar, Dhubri and Bongaigaon Districts of Assam. Report to the Assam Forest Department, Guwahati, India.

Grosh, S. (2008b) Report of Wild Elephant (Elephas maximus) Population Estimation in Bodoland Territorial Council (20-26 February 2008). Report to the Assam Forest Department, Guwahati, India.

Government of Belize (2005) The Belize National Protected Areas System Plan. Ministry of Natural Resources and the Environment, Belmopan, Belize.

Horwich, R.H. (2005) Communities saving Wisconsin birds: north and south. Passenger Pigeon, 67, 85-98.
Horwich, R.H. \& Lyon, J. (1995) Multi-level conservation and education at the Community Baboon Sanctuary, Belize. In Conserving Wildlife: International Education and Communication Approaches (ed. S.K. Jacobson), pp. 235-253. Columbia University Press, New York, USA.

Horwich, R.H. \& Lyon, J. (2007) Community conservation: practitioners' answer to critics. Oryx, 41, 376-385.

IUCN (2008) 2008 IUCN Red List of Threatened Species. IUCN, Gland, Switzerland. Http://www.iucnredlist.org [accessed 26 February 2009].

Jha, M. (2000) Policies on Joint Forest Management and its implementation in Maharashtra. Indian Forester, 126, 917-922.

KothaRI, A. (1996) Is joint management of protected areas desirable and possible? In People \& Protected Areas (eds A. Kothari, N. Singh \& S. Suri), pp. 17-49. Sage Publications, New Delhi, India.

KRISHNAN, B.J. (1996) Legal implications of joint management of protected areas. In People \& Protected Areas (eds A. Kothari, N. Singh \& S. Suri), pp. 70-81. Sage Publications, New Delhi, India.

McShane, T.O. \& Wells, M.P. (eds) (2004) Getting Biodiversity Projects to Work. Columbia University Press, New York, USA.

Mukherjee, R.P. \& Southwick, C.H. (1997) Present status of the golden langur in Assam, India. Asian Primates, 6, 1-4.

NABARD (National Bank for Agriculture and RuRal Development) (2004) Handbook on Forming Self-Help Groups (SHGs). NABARD, Mumbai, India.

NaCSO (Namibia Association of Community Based Natural Resource Management (CBNRM) Support Organisations) (2008) Namibia's Communal Conservancies: A Review of Progress and Challenges in 2007. NACSO, Windhoek, Namibia.

Pатнак, N. (2002) Implications of existing and proposed laws and policies on community forestry initiatives in India. Inform, 2, 5-11.

Poffenberger, M. \& Gean, B. (1996) Village Voices, Forest Choices. Oxford University Press, Delhi, India.

Rastogi, A. (2000) Joint Forest Management in India. Surya International Publications, Dehra Dun, India.

Robinson, J.G. \& REDFORD, K.H. (2004) Jack of all trades, master of none: inherent contradictions among ICD approaches. In Getting Biodiversity Projects to Work (eds T.O. McShane \& M.P. Wells), pp. 10-34. Columbia University Press, New York, USA.

Schön, D.A. (1983) The Reflective Practitioner: How Professionals Think in Action. Basic Books, New York, USA.

Sing H, C. (2000) India's Forest Policy and Forest Laws. Nataraj Publishers, Dehra Dun, India.

Sing , S.P. (1999) Manas at a Glance. Saraighat Printers, Guwahati, Assam, India.

Srivastava, A. (1999) Primates of North-east India. Megadiversity Press, Bikaner, India.

SRivastava, A. (2004) Long-term Eco-behavioral Studies of Golden Langurs: Population Dynamics and Conservation. Progress Report to Primate Action Fund Conservation International, Washington, DC, USA.

Srivastava, A., Biswas, J., Das, J. \& Bujarbarua, P. (2001) Status and distribution of golden langurs (Trachypithecus geei) in Assam, India. American Journal of Primatology, 55, 15-23.

WANGCHUK, T. (1995) A census and the biogeography of golden langurs (Presbytis geei) in Bhutan. Tigerpaper, 22, 1-6.

Westley, F., Zimmerman, B. \& Patton, M.Q. (2006) Getting to Maybe: How the World is Changed. Random House, New York, USA.

Wildlife Protection Society (2003) The Wildlife (Protection) Act, 2002 (16 of 2003) (with effect from 1-4-2003). Professional Book Publishers, New Delhi, India.

Wildlife Protection Society of India (1998) Handbook of Environment, Forest \& Wildlife Protection Laws in India. Nataraj Publishers, Dehra Dun, India. 
WiLSON, K. (2002) The new microfinance-an essay on the self-help movement in India. Journal of Microfinance, 4, 217-245.

Young, C. \& Horwich, R.H. (2007) History of protected areas designation, co-management and community participation in Belize. In Taking Stock: The First 25 Years of Belizean Independence (eds B.S. Balboni \& J.O. Palacio), pp. 123-150. Cubola Productions, Benque Viejo del Carmen, Belize.

Yunus, M. (1999) Banker to the Poor. Public Affairs, New York, USA.

\section{Biographical sketches}

The authors are part of the Golden Langur Conservation Project and the Manas Biosphere Conservation Forum. Robert Horwich has catalysed community conservation projects in 12 countries, researches primate behaviour and ecology, development in birds and mammals, and wildlife reintroductions. RAJEN ISLARI began his conservation efforts in 1996 with the Indo-US Primate Project and plays a pivotal role in the Forest Protection Forces. Arna B Bose, a butterfly expert and researcher, coordinates community field conservation efforts in Kakoijana. BABLU Dey coordinates the field programme on the Chakrashila/Nadangiri complex. Mahesh Moshahary coordinates conservation and research in the Manas Reserve Forest. NirmaL Kanti Dey coordinates the community protection forces within the Manas Biosphere Reserve. RAJU Das researches golden langur behavior and ecology in Kakoijana Reserve Forest. Jon A THAN LYON, an ecologist, has worked as an associate of Community Conservation in many projects. 